\title{
In vitro and in vivo assessment of orf virus (ORFV) by electron microscopy
}

\author{
Nawab Nashiruddullah ${ }^{1 *}$, Debesh C. Pathak ${ }^{1}$, Nagendra N. Barman ${ }^{2}$, \\ Jafrin A. Ahmed ${ }^{3}$, Probodh Borah ${ }^{4}$, Safeeda S. Begum ${ }^{5}$, and Saidul Islam ${ }^{6}$ \\ ${ }^{\prime}$ Department of Veterinary Pathology, College of Veterinary Science, Assam Agricultural University, \\ Guwahati, Assam, India \\ ${ }^{2}$ Department of Veterinary Microbiology, College of Veterinary Science, Assam Agricultural University, \\ Guwahati, Assam, India \\ ${ }^{3}$ Division of Veterinary Physiology and Biochemistry, Faculty of Veterinary Sciences and Animal Husbandry, \\ Sher-e-Kashmir University of Agricultural Sciences and Technology-Jammu, RS Pura, Jammu and Kashmir, \\ India \\ ${ }^{4}$ State Biotechnology Hub, College of Veterinary Science, Assam Agricultural University, Guwahati, Assam, \\ India \\ ${ }^{5}$ Department of Veterinary Medicine, College of Veterinary Science, Assam Agricultural University, Guwahati, \\ Assam, India \\ ${ }^{6}$ Department of Veterinary Parasitology, College of Veterinary Science, Assam Agricultural University, \\ Guwahati, Assam, India
}

NASHIRUDDUllah, N., D. C. PATHAK, N. N. BARMAN, J. A. AHMED, P. BORAH, S. S. BEGUM, S. ISLAM: In vitro and in vivo assessment of orf virus (ORFV) by electron microscopy. Vet. arhiv 88, 847-861, 2018.

\section{ABSTRACT}

Transmission electron microscopy (TEM) was employed for describing skin and scab lesions in goats affected by orf virus and to demonstrate the parapoxvirus from clinical suspensions by negative staining and ORFV confirmation by immunogold electron microscopy. All samples were confirmed as parapoxvirus by semi-nested PCR amplification of partial gene encoding for the B2L envelope protein. Skin lesions were characterized by ballooning degeneration and loss of desmosomes of the spinosum cells, cytolysis and vesicle formation. Nuclear changes included chromatin margination and increase in electron density. Cytoplasmic changes were typical of cell swelling, vacuolation and the presence of uniform, moderately electron dense viroplasm, situated in the perinuclear region. Various intracellular forms including immature virions (IV), mature virions (IMV) and wrapped virions (WV) were observed in the cytoplasm. All these forms of ORFV were observed morphologically akin to vaccinia virus (VACV). Negative staining of clinical samples and viral suspensions showed typical parapoxvirus morphology with a characteristic criss-cross tubular surface

\footnotetext{
*Corresponding author:
}

Nawab Nashiruddullah, Division of Veterinary Pathology, Faculty of Veterinary Sciences and Animal Husbandry, Sher-eKashmir University of Agricultural Sciences and Technology-Jammu, RS Pura-181102, Jammu and Kashmir, India, Phone: +91 192325 0242; Fax: +91 192325 0639; E-mail: nawabn1@rediffmail.com 
pattern. Both 'capsule' form ('C' form) and 'mulberry' form ('M' form) of the virus were demonstrated. ORFV speciation was confirmed by immunogold tagging using a monoclonal antibody in ultra-thin skin section.

Key words: goat; gold labelling; orf virus; electron microscopy; parapoxvirus

\section{Introduction}

The first morphological study of the contagious ecthyma agent or orf virus (ORFV) was attempted by BORCILA and ISOPESCU (1937), but they failed to demonstrate the virus. Morphological descriptions of the agent became possible after the advent of the electron microscope (EM) which has since been used in the discovery and description of new viruses. Thereafter, ABDUSSALAM and COSSLETT (1957) were successful for the first time in demonstrating orf virus as short monomorphic rods, and describing its morphological and staining characteristics under a light and electron microscope.

The oval-shaped parapox virions under the EM have been well-defined (VIKØREN et al., 2008). Parapoxviruses are indistinguishable from each other under the EM, but can easily be discerned by negative stain EM from the other larger poxviruses, that are brickshaped with irregular short surface filaments.

Descriptions of ultrastructural changes in cells and tissues associated with ORFV infection have been scarce in the literature and largely limited to mere demonstration of virus in clinical specimens. The present study was conducted to describe spontaneous dermal lesions in affected animals and demonstration of intracellular viral particles. Moreover, electron microscopy was evaluated as a rapid diagnostic tool for examining clinical and laboratory samples for confirmatory diagnosis of parapoxvirus infection. Speciation of ORFV, while differentiating from other parapoxvirus using a commercial monoclonal antibody (2E5), was also attempted probably for the first time using immunogold electron microscopy.

\section{Materials and methods}

Virus. For TEM imaging with negative staining, two types of ORFV isolates were used:

(i) Reference virus isolate: Live attenuated vaccine virus (OrfMuk 59/05, batch 06/09) isolated from goats and previously propagated in primary lamb testis cells (PLT) produced at the poxvirus disease laboratory, Division of Virology, Mukteshwar, was used as a reference ORFV strain.

(ii) Field/wild type virus isolates: Apart from the vaccine virus, seven other virus preparations from clinical samples, cell culture supernatant and discontinuous sucrose gradient preparations were examined. Virus suspensions were prepared from infected tissue or scabs collected from clinically infected goats. Skin scabs and tissue biopsy samples were homogenized with a sterile pestle and mortar with $\sim 1 \mathrm{~mL}$ sterile distilled water to an opalescent suspension. This was clarified by centrifugation at $1,000 \times \mathrm{g}$ for $5 \mathrm{~min}$ and the supernatant passed through a $0.45 \mu$ pore filter (Millipore) and used directly as EM specimen. 
One sample was processed and isolated in continuous foetal lamb testis cells (OA3.Ts, ATCC $^{\circledR}$ CRL-6546TM) as described earlier (NASHIRUDDULLAH et al., 2016). A scab derived tissue lysate (SON02) was processed and partially purified with discontinuous sucrose gradient ultracentrifugation, as described by JOKLIK (1962).

Antibody. A commercially available mouse monoclonal orf virus (2E5) antibody (Santa Cruz Biotechnology Inc., sc101589), raised against scab-derived orf virus isolated from sheep, was used for immunolocalization of the viral antigen.

Tissue samples. Tissues samples for transmission electron microscopy were obtained from shed scabs and incision biopsy of skin from clinically affected goats. The study was approved by the Institutional Animal Ethics Committee (IAEC) under CPCSEA (Approval No. 99/IAEC-697/2013-14/DRV/2888-93, dated 13/09/2013).

Electron microscopy. The transmission electron microscopy (TEM) was employed to: (i) examine the ultrastructural details of affected tissues and ORFV by thin section, (ii) demonstrate the surface morphology of parapoxvirus in direct clinical sample suspensions by negative staining, (iii) demonstrate ORFV in tissues by immuno-electron microscopy (IEM) with monoclonal antibody. A transmission electron microscope (Jeol, JEM-2100, $200 \mathrm{kV}$ ) was used in this study.

For conventional TEM and IEM, skin tissues were trimmed into $1.0-1.5 \mathrm{~mm}$ cube sizes and primarily fixed in 1\% Karnovsky's fixative prepared in 0.1 M Sodium cacodylate buffer ( $\mathrm{pH}$ 7.2) for $2-4$ hours at $4{ }^{\circ} \mathrm{C}$. The specimens were then washed in $0.1 \mathrm{M}$ Sodium cacodylate buffer (thrice for 15 minutes each) and stored in the same buffer at $4{ }^{\circ} \mathrm{C}$ until further use. The specimens were then washed, secondarily fixed in osmium tetroxide, and dehydrated in ascending grades of acetone, resin embedded in araldite, and ultrathin sections prepared. Sections were mounted on grids and stained with uranyl acetate and lead citrate.

For IEM, post-embedding procedure was used (DE PAUL et al., 2012) and optimized with and without osmium tetroxide $\left(\mathrm{OsO}_{4}\right)$ secondary fixation. Commercially available anti-ORFV monoclonal antibody (2E5) (Santa Cruz Biotechnology Inc., sc101589) and Protein A conjugated to $20 \mathrm{~nm}$ colloidal gold (Sigma, Protein-A $20 \mathrm{~nm}$ Colloidal Gold Labelled, \#P6855) were employed for immuno tagging.

TEM with negative staining was employed to directly visualize virus particles from clinical scab samples, cell culture fluids, and ultracentrifugation preparation of the virus, employing the drop-to-drop method (DOANE and ANDERSON, 1987). An aliquot of the purified virus was fixed in 1\% Karnovsky's fixative and processed for negative staining electron microscopy for demonstration of the virus, employing $2 \%$ phosphotungstic acid (PTA) or $0.5 \%$ uranyl acetate (UA).

PCR detection of Parapoxvirus. A semi-nested PCR was employed targeting the partial B2L gene encoding the virion envelope by the primer set PPP1-PPP3 and PPP1PPP4 (PPP1: GTC GTC CAC GAT GAG CAG CT; PPP3: GCG AGT CCG AGA AGA 
ATA CG; PPP4: TAC GTG GGA AGC GCC TCG CT) as described by INOSHIMA et al. (2000) for specific pan-parapoxvirus detection. For extraction of viral DNA, commercially available DNeasy Blood \& Tissue Kit (Qiagen USA, \#69504) was used according to the manufacturer's instructions. DNA was isolated from the reconstituted vaccine, cell culture lysate, and from the clinical scabs.

\section{Results}

Molecular confirmation of parapoxvirus. A total of six samples, comprising the vaccine virus, infected cell culture fluid, and clinical scab lesions were found to be positive by the semi-nested PCR. Amplification with the first set PPP1-PPP4 was able to detect the expected product size of $594 \mathrm{bp}$ and the second set of primers PPP3-PPP4 successfully amplified the appropriate sized product of $235 \mathrm{bp}$, confirming the samples to contain parapoxvirus.

Ultrastructural changes in skin lesions with positive stain TEM. Tissue samples were categorized as either shed scab lesions or intact incisional skin biopsies. At low magnification, the epidermis of skin biopsies appeared segregated into distinct layers (Fig. 1A). In other areas vesicles were prominent, and separated cells floated in the transudate. Some cells were found to undergo cytolysis (Fig. 1B). Cells of the Malpighian layer of the skin appeared to be vacuolated (Fig. 1C). The cytoplasm of the superficial stratified epithelial cells lacked most of the organelles or they were present in reduced abundance. Cells were swollen and rounded with characteristic hydropic or ballooning degeneration. The spinous cells had lost their inter digitations and become individualized. The organelles appeared swollen. In some cells, short filamentous projections were observed beneath the cell membrane (Fig. 1D). Cytoplasmic changes included the presence of myelin-like figures (Fig. 1E). Nuclei were pleomorphic and sometimes appeared hyperchromic or electron dense. In some cases a less electron-dense central zone could be found in the nucleus. The most common affection was margination of the nuclear chromatin (Fig. $1 \mathrm{~F})$. Moderately dense areas within the cytoplasm were identified as viroplasm and were often situated in the perinuclear region, within which numerous immature virions were embedded that appeared spherical with a less electron dense core. Mature virions were oval to ellipsoidal with an outer membrane and electron dense biconcave core, which became visible only in certain planes of sections. The intracellular wrapped virion appeared enclosed in two additional membranes that made their size larger and approximating 230 - $300 \mathrm{~nm}$ in length and $130-150 \mathrm{~nm}$ in width, respectively. Ultrathin cross sections of wrapped virions revealed an electron-dense core surrounded by multiple layers. The cores of wrapped virions were ovoid, lanceolate or dumbbell shaped depending on the plane of section. Extracellular enveloped viruses were similarly enclosed in multiple membranes. The ultrastructural changes and virus morphological features in the tissue and scab biopsy were indicative of poxvirus infection. 

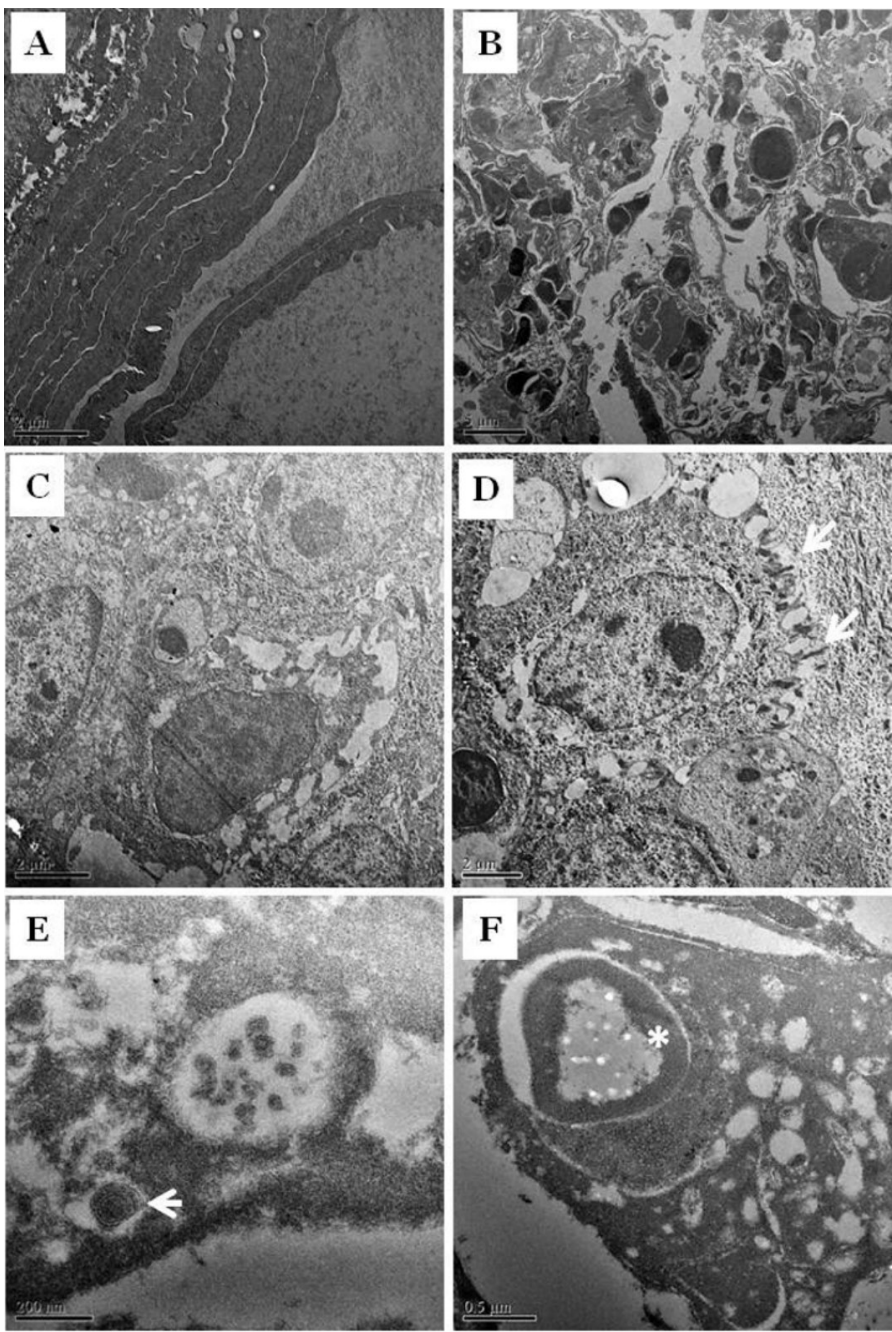

Fig. 1. Transmission electron micrograph of ORFV affected skin biopsy tissue showing various ultrastructural changes. A: segregation of epidermal layers; B: ballooning degeneration and necrosis of spinous cells; C: intracytoplasmic vacuolation of epidermal cells; D: microtubular extension near cell membrane (arrows); E: intracytoplasmic myelin-like figures (arrow); F: chromatin margination in nucleus $(*)$.

In the scabs, degeneration and necrosis of the cells were evident. Nuclear changes in some cells included pyknosis, an electron dense nucleus and often karyorrhexis. Even at 
low magnification, numerous intracellular immature and mature viral particles could be seen. Extracellular viral particles could also be seen near degenerate and necrotic cells or in clear fluid filed vesicles (Fig. 2). Various viral stages (Fig. 3) were seen including intracellular immature virus particles (IV) (Fig. 3A) and intracellular mature virions (IMV) (Figure 3B, C), wrapped virions (WV) also called the intracellular enveloped virion (IEV), and extracellular enveloped virion (EEV) (Fig. 3D).

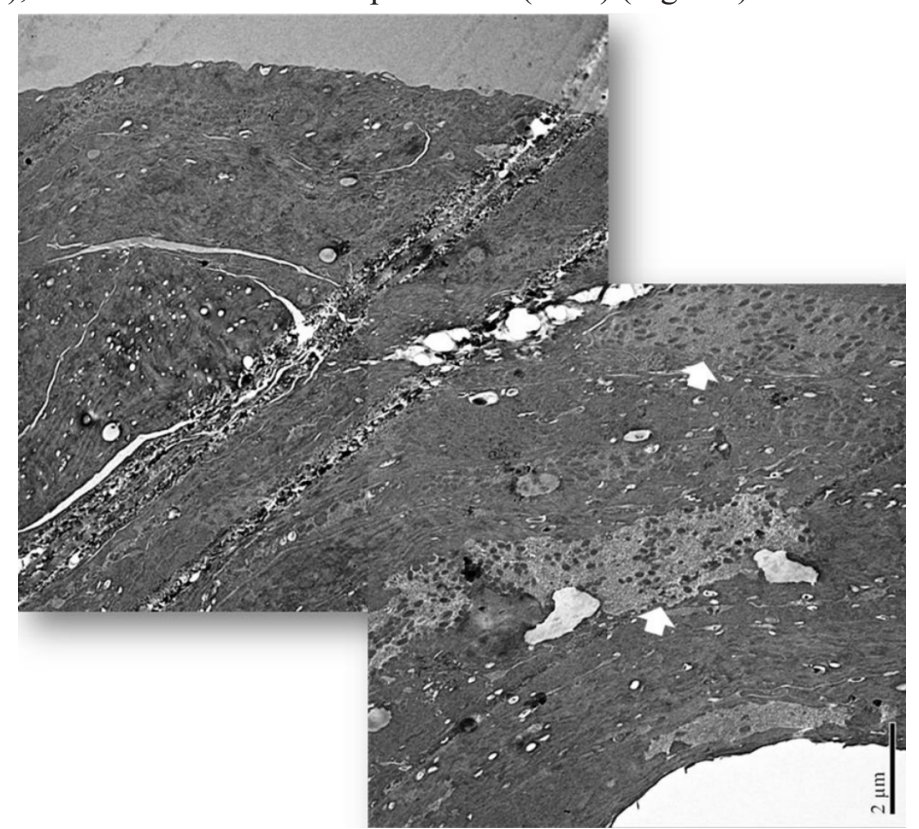

Fig. 2. Transmission electron micrograph of ORFV affected skin scab tissue showing degeneration of the epidermal cells and the presence of many mature extracellular virus particles (arrows) in fluid filed vesicles.

Virus surface morphology with negative stain TEM. The surface morphology of the virus was best studied in the negative stained preparation of five scab tissue lysates, and one each of the vaccine virus suspension, infected cell culture lysate, and sucrose gradient purified virus suspension, with either phosphotungstic acid (PTA) or uranyl acetate (Table 1). The use of uranyl acetate gave better contrast than PTA. Morphologically; the virus appeared oval in shape with a characteristic criss-cross tubular pattern on the surface. Both the 'capsule' form (' $\mathrm{C}$ ' form) and the 'mulberry' form (' $\mathrm{M}$ ' form) of the virus were seen in negative stained preparations of the samples (Fig. 4). The clear form due to its more permeable envelope showed a smooth surface without the patterns, whereas the ' $M$ ' form showed the distinct 'ball of yarn' appearance. 
The unidirectional and left-oriented filaments wrapped across and below the virus in a cross pattern as seen through it. The maximum virus was observed in directly processed scab materials. The virus particles appeared singly or in clusters. However, direct samples were often occluded for visualization and contrast staining by tissue debris, that could not be clarified. On the basis of the characteristic surface morphology of the virus in suspensions, infection with parapoxvirus at genus level was confirmed. The virus size observed by negative TEM also ranged within $230-300 \mathrm{~nm}$ in length and $130-150 \mathrm{~nm}$ in width.

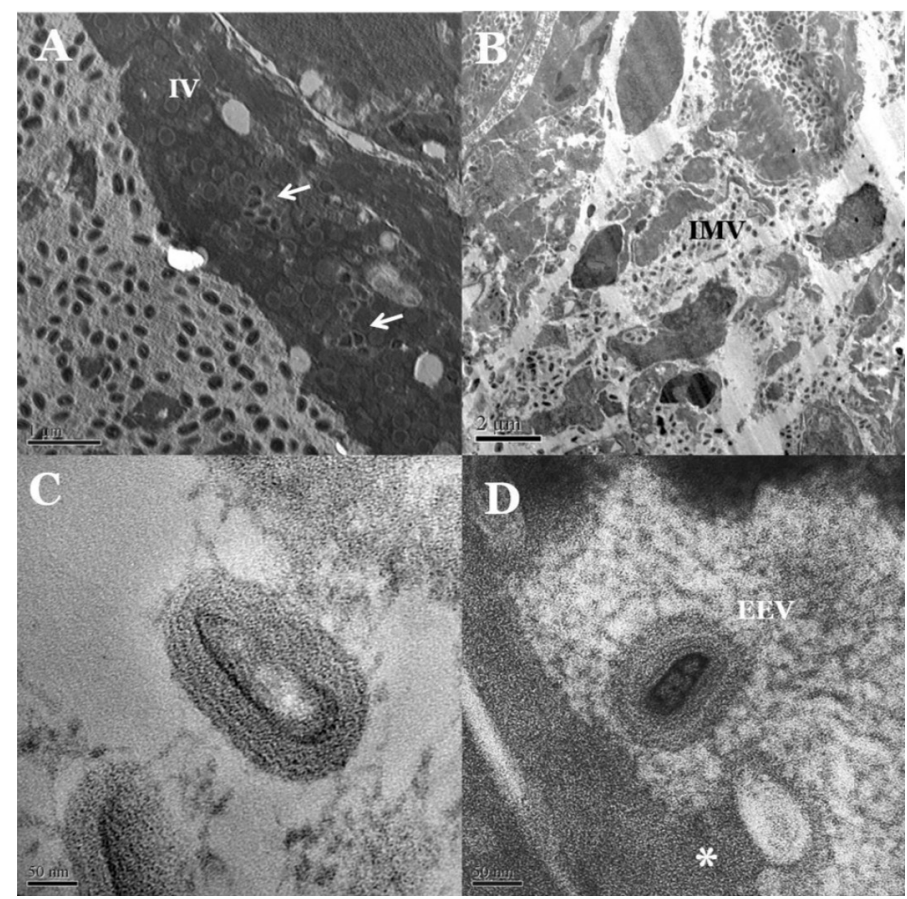

Fig. 3. Different stages of intracellular ORFV in affected epidermal cells observed under electron microscope. A: Viroplasm containing immature virions (IV) undergoing maturation (arrows) to evolve into intracellular mature virions (IMV); B, C: intracellular mature virions (IMV); D: extracellular enveloped virion (EEV) associated with another virion during egress mediated by an actin tail $(*)$.

Immunoelectron microscopy. Duplicate ultrathin sections of scab and biopsy tissues were processed for in situ localization and confirmation of the intracellular virus with ORFV monoclonal antibody, conjugated with electron dense $20 \mathrm{~nm}$ colloidal gold (Fig. 5). With this technique the virus could successfully be identified in the samples immunologically at the species level as belonging to ORFV. Interestingly, the nano-gold 
N. Nashiruddullah et al.: Electron microscopic assessment of orf virus (ORFV)

could only tag the IMV and not the IEV/WV. In addition, sections fixed in OsO4 were better in contrast.

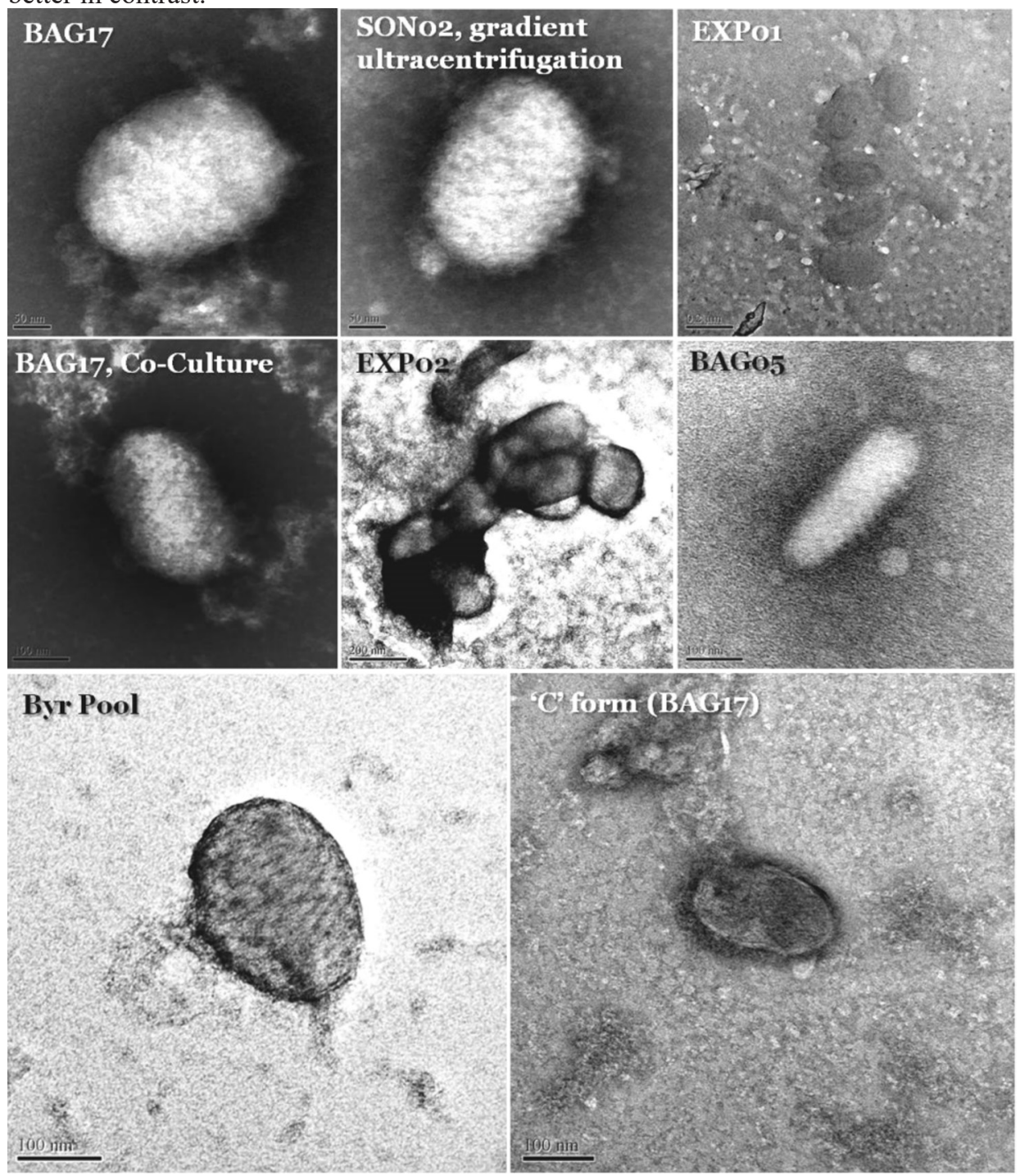

Fig. 4. Surface morphology of ORFV by negative staining transmission electron microscopy. 'C' (capsule/smooth) form virus did not present surface tubular morphology. All other viruses shown are 'M' (mulberry) form. All preparations stained with Uranyl acetate. 
N. Nashiruddullah et al.: Electron microscopic assessment of orf virus (ORFV)

Table 1. Negative transmission electron microscopy of different samples for detection of parapoxvirus (ORFV) in goats

\begin{tabular}{|l|c|c|}
\hline Sample ID & Sample type & Remarks \\
\hline BAG05 & Scab derived lysate & Distinct surface tubules \\
\hline BAG17 & Scab derived lysate & Both 'M' and 'C' form \\
\hline EXP01 & Scab derived lysate & Phosphotungstic acid stain \\
\hline EXP02 & Scab derived lysate & Distinct surface tubules \\
\hline Byr pool & Scab derived lysate & Distinct surface tubules \\
\hline SON02 & Sucrose gradient purified virus & Distinct surface tubules \\
\hline BAG17 CoC & BAG17 infected cell culture lysate & Distinct surface tubules \\
\hline VACC & Vaccine virus infected cell culture & Distinct surface tubules \\
\hline
\end{tabular}

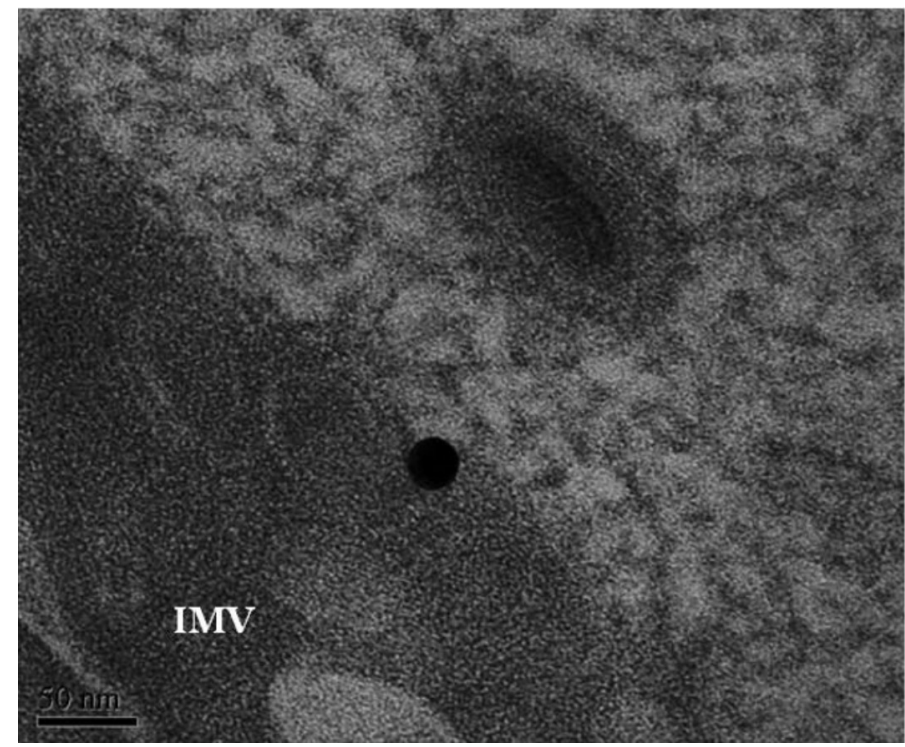

Fig. 5. Immunoelectron microscopy for detection of intracellular ORFV in affected skin tissues. Protein A-gold $(20 \mathrm{~nm})$ conjugate was used to detect anti-ORFV monoclonal antibody tagged intracellular mature virions (IMV) in viroplasm.

\section{Discussion}

When envisioned by negative stain EM, the spiral tubule patterns encircling the parapoxviruses are distinctive (NAGINTON and HORNE, 1962) and have been used for confirmatory diagnosis of parapoxvirus infection from clinical samples. The other 
morphological distinctive features were the ovoid to ellipsoid shape, and the rather large size of the virus. These features distinctly identify parapoxviruses from other viruses and particularly other chordopoxviruses, that are brick-shaped and even larger. Although negatively stained preparations may be used directly for rapid diagnosis of parapoxvirus infection, speciation is not possible within the genus. The dimensions of the virus observed were similar to earlier reports for extracellular viruses observed by negative TEM (ABDUSSALAM and COSSLETT, 1957; NAGINTON and HORNE, 1962; COUCH, 1983; DOANE and ANDERSON, 1987; VIKØREN et al., 2008). Variations in size in TEM preparation may probably arise from defects in the sample preparation. The ' $\mathrm{C}$ ' form of the virus is sometimes visible in EM preparations where the stain penetrates the virion (NAGINTON and HORNE, 1962; MITCHINER, 1969; ROBINSON and BALASSU, 1981), and a finely crenelate membrane appears to surround an inner amorphous core. It is also notable for its dark staining centre that appears electron dense (COUCH, 1983). Virions that were impervious to the stain reveal a regular array of tubule-like structures arranged in a criss-cross manner (NAGINTON and HORNE, 1962; MITCHINER, 1969). Where the virus has been propagated in cell culture, virions that appear in the medium are surrounded by a membranous structure (TAN et al., 2009). The negative staining of clinical samples and subsequent observation under the electron microscope is probably the most rapid method for confirming the presence of parapoxvirus. Initial clarification is required to remove tissue debris. Depending on the amount of virus in the sample, low concentrations may require some time to scan and identify viruses, but once detected, it is fairly confirmatory. In the present study, both phosphotungstic acid and uranyl acetate were used for contrast staining, however, the best results were found with uranyl acetate. This was probably because of the finer grains in uranyl acetate that gave a higher electron density and image contrast (GOLDSMITH and MILLER, 2009); and it also helped to fix the specimen.

The ultrastructural findings, mature and immature virions in infected cells and complete virions extracellularly are akin to the observations of POSPISCHIL and BACHMANN (1980) including the nuclear changes, except for their observations on fine intranuclear filaments arranged singly or in bundles that were associated with degenerative changes. Comparable descriptive changes for scab and tissue lesions are scarce in the literature.

The observations of the viroplasm in the present study were similar to the description of TOLONEN et al. (2001) for vaccinia virus (VACV) as being uniformly dense and devoid of cellular organelles within the host cytoplasm. There was a relative abundance and ease of identification of numerous viral particles in scab lesions in comparison with the biopsy lesions. This probably depends on the replicative stage of the virus. The increased replicative phase of the virus in the initial infective stage is contained within the scab, and with its subsequent shedding, it becomes a source of contamination 
and dissemination of the infective virus in the environment. This was also seen in the abundant number of complete virions demonstrated in the vesicular fluid within the scab. It has been estimated that between $7 \times 109$ and $1.6 \times 1011$ virus particles can be recovered from one gram of scab material (ROBINSON et al., 1982). The descriptions of the virion stages in the present study were based largely on the VACV, to which the ORFV is closely related. The immature virions (IV) were similarly described as spherical structures that contained the viral core proteins and the genome (SODEIK et al., 1993; RISCO et al., 2002). These immature virions (IV) mature to intracellular mature virions (IMV) that were said to represent the majority of infectious progeny, and most remain within the infected cell until cell lysis (ZHANG et al., 2000). In the VACV, the transition between these IV and intracellular mature virions (IMV) involves a major morphological change from spherical to brick-shaped virions. This was also observed in the present investigation where the ORFV changed shape from a spherical to the rather ellipsoidal form typical for parapoxvirus. The observed IMV were similar to those described for ORFV in ultrathin sections of infected cells (SPEHNER et al., 2004) and VACV (MALKIN et al., 2003; HEUSER, 2005) as exhibiting a more complex structure, consisting of an outer membrane, a biconcave core, and two lateral bodies.

The IEV or WV was also identified akin to the description of SPEHNER et al. (2004) who described their similarities with VACV in ultrathin sections of ORFV infected cells. Some IMV particles were described to have been transported away from the virus factory in a process that is dependent upon microtubules (SANDERSON et al., 2000) to sites where they became wrapped with two additional cellular membranes (ICHIHASHI et al., 1971). Descriptions of these virus forms have been reported in detail for VACV. The additional membranes are reportedly derived from the tubular endosomes (TOOZE et al., 1993) or trans-Golgi network (HILLER and WEBER, 1985; SCHMELZ et al., 1994) that has been modified by the inclusion of virus-encoded proteins. Some IMV were found near the cell surface that often protruded through the membrane. This has been described as viral transportation along microtubules and actin filaments to the cell surface, and aided by polymerization of actin tails that protrude from the cell surface with an enveloped virion at their tip (CUDMORE et al., 1995). Studies with ORFV recombinants expressing FLAG-tagged envelope structural proteins suggest that ORFV also has both MV and WV forms, and that a minority of particles egress from the cell as EVs as in VACV (TAN et al., 2009).

\section{Conclusion}

The present study strongly corroborates the reported findings of various intracellular forms of ORFV similar to VACV. The abundance of the EV forms, particularly in scabs, suggest their infective nature; the scabs aid in virus survival and act as a source of virus dissemination in the environment. 


\section{N. Nashiruddullah et al.: Electron microscopic assessment of orf virus (ORFV)}

\section{Conflicts of interest}

The authors declare no conflict of interest.

\section{Acknowledgements}

The study was part of $\mathrm{PhD}$ research by the first author, and all help rendered is duly acknowledged. The authors wish to thank Dr. (Mrs) Begonia Dkhar, In-charge of Sophisticated Analytical Instrumentation Facility, NorthEast Hill University, Shillong, for the TEM facilities. Thanks are also due to the supporting staff: Mr. Joston P. Nongkynrih, Mr. Batskhem Dohtsong, Mrs. Anjali Haloi, Mr. Dannis Bareh and Mr. Milford Thangkhiew from the TEM Preparation and Imaging section.

\section{References}

ABDUSSAlAM, M., V. E. COSSLETT (1957): Contagious pustular dermatitis. I. Studies on morphology. J. Comp. Pathol. Ther. 67, 145-156.

DOI: $10.1016 / \mathrm{S} 0368-1742(57) 80014-9$

BORCILA, J., I. ISOPESCU (1937): Contagious ecthyma in sheep in Rumania. Arch. Vet. 29, $16-54$.

COUCH, A. J. (1983): The development of, and host response to, ovine contagious pustular dermatitis. BSc (Hons.), University of New England, Armidale, N.S.W.

CUDMORE, S., P. COSSART, G. GRIFFITHS, M. WAY (1995): Actin-based motility of vaccinia virus. Nature 378, 636-638.

DOI: $10.1038 / 378636 \mathrm{a} 0$

DE PAUl, A. L., J. H. MUKDSi, J. P. PETITI, S. GUTIÉRREZ, A. A. QUinTAR, A. A. MALDONADO, A. I. TORRES (2012): Immunoelectron microscopy: a reliable tool for the analysis of cellular processes. In: Applications of Immunocytochemistry. (Dehghani, H., Ed.), InTech Europe, Croatia, pp. 65-96.

DOI: $10.5772 / 33108$

DOANE, F. W., N. ANDERSON (1987): Electron Microscopy in Diagnostic Virology: A Practical Guide and Atlas. Cambridge University Press, Cambridge, New York, pp. 14-31.

GOLDSMITH, C. S., S. E. MILLER (2009): Modern uses of electron microscopy for detection of viruses. Clin. Microbiol. Rev. 22, 552-563.

DOI: 10.1128/CMR.00027-09

HEUSER, J. (2005): Deep-etch EM reveals that the early poxvirus envelope is a single membrane bilayer stabilized by a geodetic "honeycomb" surface coat. J. Cell Biol. 169, 269-283.

DOI: $10.1083 /$ jcb.200412169

HILLER, G., K. WEBER (1985): Golgi-derived membranes that contain an acylated viral polypeptide are used for vaccinia virus envelopment. J. Virol. 55, 651-659.

ICHIHASHI, Y., S. MATSUMOTO, S. DALES (1971): Biogenesis of poxviruses: role of A-type inclusions and host cell membranes in virus dissemination. Virology 46, 507-532.

DOI: 10.1016/0042-6822(71)90056-0 
N. Nashiruddullah et al.: Electron microscopic assessment of orf virus (ORFV)

INOSHIMA, Y., A. MOROOKA, H. SENTSUI (2000): Detection and diagnosis of parapoxvirus by the polymerase chain reaction. J. Virol. Methods 84, 201-208.

DOI: 10.1016/S0166-0934(99)00144-5

JOKLIK, W. K. (1962): The purification of four strains of poxvirus. Virology 18, 9-18.

DOI: 10.1016/0042-6822(62)90172-1

MALKIN, A. J., A. McPHERSON, P. D. GERSHON (2003): Structure of intra-cellular mature vaccinia virus visualized by in situ atomic force microscopy. J. Virol. 77, 6332-6340.

DOI: $10.1128 / J V I .77 .11 .6332-6340.2003$

MITCHINER, M. B. (1969): The envelope of vaccinia and orf viruses: an electron cytochemical investigation. J. Gen. Virol. 5, 211-220.

DOI: $10.1099 / 0022-1317-5-2-211$

NAGINTON, J., R. W. HORNE (1962): Morphological studies of orf and vaccinia viruses. Virology 16, 248-260.

DOI: $10.1016 / 0042-6822(62) 90245-3$

NASHIRUDDDULLAH, N., D. C. PATHAK, N. N. BARMAN, J. A. AHMED, G. RAJBONGSHI, R. K. SHARMA, P. BORAH, S. S. BEGUM (2016): Evaluation of ORFV isolation in continuous lamb testis cells (OA3.Ts) and development of a co-culture method with infected cells that may increase infectivity. Indian J. Anim. Res. 50, 951-957.

DOI: 10.18805/ijar.v0i0f.3786

POSPISCHIL, A., P.A. BACHMANN (1980): Nuclear changes in cells infected with parapoxviruses stomatitis papulosa and orf: an in vivo and in vitro ultrastructural study. J. Gen. Virol. 47, 113121.

DOI: $10.1099 / 0022-1317-47-1-113$

RISCO, C., J. R. RODRIGUEZ, C. LOPEZ-IGLESIAS, J. L. CARRASCOSA, M. ESTEBAN, D. RODRIGUEZ (2002): Endoplasmic reticulum-Golgi intermediate compartment membranes and vimentin filaments participate in vaccinia virus assembly. J. Virol. 76, 1839-1855.

DOI: $10.1128 /$ JVI.76.4.1839-1855.2002

ROBINSON, A. J., T. C. BALASSU (1981): Contagious pustular dermatitis (orf). Vet. Bull. 51, 771-782.

ROBINSON, A. J., G. ELLIS, T. BALASSU (1982): The genome of orf virus: restriction endonuclease analysis of viral DNA isolated from lesions of orf in sheep. Arch. Virol. 71, 43-55.

DOI: $10.1007 / \mathrm{BF} 01315174$

SANDERSON, C. M., M. HOLLINSHEAD, G. L. SMITH (2000): The vaccinia virus A27L gene is needed for the microtubule-dependent transport of intracellular mature virus particles. J. Gen. Virol. 81, 47-58.

DOI: 10.1099/0022-1317-81-1-47

Vet. arhiv 88 (6), 847-861, 2018 
SCHMELZ, M., B. SODEIK, M. ERICSSON, E. WOLFFE, H. SHIDA, G. HILLER, G. GRIFFITHS (1994): Assembly of vaccinia virus: the second wrapping cisterna is derived from the trans Golgi network. J. Virol. 68, 130-147.

SODEIK, B., R. W. DOMS, M. ERICSSON, G. HILLER, C. E. MACHAMER, W. VAN'T HOF, G. VAN MEER, B. MOSS, G. GRIFFITHS (1993): Assembly of vaccinia virus: role of the intermediate compartment between the endoplasmic reticulum and the Golgi stacks. J. Cell Biol. 121, 521-541.

DOI: $10.1083 /$ jcb.121.3.521

SPEHNER, D., S. DE CARLO, R. DRILLIEN, F. WEILAND, K. MILDNER, D. HANAU, H. J. RZIHA (2004): Appearance of the bona fide spiral tubule of ORF virus is dependent on an intact 10-kilodalton viral protein. J. Virol. 78, 8085-8093.

DOI: 10.1128/JVI.78.15.8085-8093.2004

TAN, J. L., N. UEDA, A. A. MERCER, S. B. FLEMING (2009): Investigation of orf virus structure and morphogenesis using recombinants expressing FLAG-tagged envelope structural proteins: evidence for wrapped virus particles and egress from infected cells. J. Gen. Virol. 90, 614-625. DOI: 10.1099/vir.0.005488-0

TOLONEN, N., L. DOGLIO, S. SCHLEICH, J. K. LOCKER (2001): Vaccinia virus DNA replication occurs in endoplasmic reticulum-enclosed cytoplasmic mini-nuclei. Mol. Biol. Cell 12, 2031-2046.

DOI: $10.1091 / \mathrm{mbc} \cdot 12.7 .2031$

TOOZE, J., M. HOLLINSHEAD, B. REIS, B. K. RADSAK, H. KERN (1993): Progeny vaccinia and human cytomegalovirus particles utilize early endosomal cisternae for their envelopes. Eur. J. Cell Biol. 60, 163-178.

VIKøREN, T., A. LillehaugA J. ÅKerstedtB, T. BRETTENC, M. HAUGUMD, M. TRYLANDE (2008): A severe outbreak of contagious ecthyma (orf) in a free-ranging musk ox (Ovibos moschatus) population in Norway. Vet. Microbiol. 127, 10-20.

DOI: 10.1016/j.vetmic.2007.07.029

ZHANG, W. H., D. WILCOCK, G. L. SMITH (2000): Vaccinia virus F12L protein is required for actin tail formation, normal plaque size, and virulence. J. Virol. 74, 11654-11662.

DOI: 10.1128/JVI.74.24.11654-11662.2000

Received: 27 January 2018

Accepted: 10 June 2018 


\section{NASHiRUdDUllah, N., D. C. PATHAK, N. N. BARMAN, J. A. AHMED, P. BORAH, S. S. BEGUM, S. ISLAM: Procjena orfvirusa (ORFV) in vitro i in vivo elektronskom mikroskopijom. Vet. arhiv 88, 847-861, 2018.}

\section{SAŽETAK}

U radu je za opisivanje lezija na koži i krastama kod koza inficiranih orfvirusom primijenjena transmisijska elektronska mikroskopija (TEM). Dokaz parapoksvirusa iz suspenzije i potvrda ORFV-a obavljeni su tehnikom negativnog bojenja te imunogold elektronskom mikroskopijom. Svi su uzorci potvrđeni kao parapoksvirusi pomoću poluugniježđene lančane reakcije polimerazom kojom je umnožen dio gena B2L odgovornog za protein ovojnice. Lezije na koži karakterizirane su balonskom degeneracijom i gubitkom dezmosoma spinoznih stanica, citolizom te stvaranjem vezikula. Promjene u jezgri uključivale su rub kromatina i povećanje elektronske gustoće. Citoplazmatske promjene bile su tipične za bubrenje stanica, vakuolaciju i prisutnost uniformnog, umjereno elektronički gustog viroplazma smještenog u međumembranskom području. U citoplazmi su zabilježeni različiti unutarstanični oblici, uključujući nezrele virione (IV), zrele virione (IMV) i omotane virione (WV). Svi su oblici ORFV-a pokazali morfološku srodnost s virusom vakcinije (VACV). Negativno bojenje uzoraka i suspenzija pokazali su tipičnu građu parapoksvirusa s karakterističnim križno-cjevastim uzorkom na površini. Također, prikazana su oba oblika virusa, kapsula (oblik C) i dud (oblik M). Specijacija ORFV-a potvrđena je imunogold obilježavanjem pri čemu su korištena monoklonska protutijela u ultratankom rezu kože.

Ključne riječi: koza; imunogold, orf virus; elektronska mikroskopija; parapoks virus 
